\title{
FUNGSI LEMANG DALAM UPACARA PERKAWINAN SUKU BESEMAH DI KABUPATEN KAUR PROVINSI BENGKULU
}

\author{
THE LEMANG FUNCTIONS IN MARRIAGE CEREMONIES \\ OF BESEMAH TRIBE IN KAUR REGENCY \\ BENGKULU PROVINCE
}

\author{
Refisrul \\ Balai Pelestarian Nilai Budaya Sumatera Barat \\ J1. Raya Belimbing No, 16 A Kuranji Padang \\ Email: refisruljon@yahoo.co.id
}

DOI: $10.36424 / j p s b . v 5 i 2.141$

Naskah Diterima:19 September 2019 Naskah Direvisi:30 September 2019

Naskah Disetujui: 9 Oktober 2019

\begin{abstract}
ABSTRAK
Lemang adalah sejenis makanan yang terbuat dari beras ketan (pulut) yang dicampur dengan air kelapa (santan) serta garam. Kemudian dimasukkan kedalam bambu yang sudah berlapis daun pisang muda, selanjutnya dimasak pada perapian yang telah disiapkan. Membuat lemang (melemang) telah menjadi tradisi masyarakat Besemah sejak dahulu. Biasanya dilaksanakan pada waktu-waktu tertentu, seperti pada bulan puasa (Ramadhan), lebaran, maulud nabi, upacara perkawinan, panen padi, menyambut tamu dan lainnya. Keberadaan (fungsi) lemang dalam upacara perkawinan (bimbang) suku Besemah di Kabupaten Kaur merupakan fokus kajian ini. Penelitian menggunakan pendekatan kualitatif dengan sifat penelitian deskriptif analisis.Hasil penelitian menunjukkan bahwa lemang pada suku Besemah di Kabupaten Kaur menjadi unsur penting bagi keabsahan sebuah perkawinan.Lemang merupakan bawaan wajib pihak laki-laki (lanang) kepada pihak perempuan (gadis) dalam upacara perkawinan masyarakat Besemah.
\end{abstract}

Kata kunci : lemang, upacara perkawinan, suku Besemah

\section{ABSTRACT}

Lemang is a food made from of glutinous rice (pulut) mixed with santan kelapa and salt, which is then put into bamboo which has been coated in young banana leaves, then cooked on a prepared fireplace. Making lemang (melemang) has become a tradition in the Besemah community since long ago at certain times, such as during the fasting month (Ramadan), Eid, Maulud prophet, marriage ceremonies, rice harvest, welcoming guests and others. The existence of lemang in the Besemah tribe marriage ceremony (wavering) in Kaur Regency is the focus of this study. The study uses a qualitative approach by applying descriptive analysis 
research. The results showed that the lemang in the Besemah tribe in Kaur District became an important element for the validity of a marriage. Lemang is mandatory for men (lanang) to women (gadis) in the Besemah community wedding ceremony.

Keywords: lemang, marriage ceremony, Besemah ethnic group

\section{PENDAHULUAN}

Setiap masyarakat (suku bangsa) memiliki makanan tradisional dalam kehidupan sehari-hari yang merupakan warisan turun temurun dari leluhurnya. Menurut Kamus Umum Bahasa Indonesia, (1976: 188), makanan tradisional adalah segala sesuatu yang dikonsumsi masyarakat suatu daerah secara turun temurun guna memenuhi kebutuhan nutrisi bagi tubuhnya. Dari sudut ilmu Antropologi atau folklor, makanan merupakan fenomena kebudayaan, oleh karena itu makanan bukanlah sekedar produksi organism dengan kualitas-kualitas biokimia, yang dapat dikonsumsi oleh organisasi hidup, termasuk juga untuk mempertahankan hidup mereka, melainkan anggota suatu kolektif, makanan selalu ditentukan oleh kebudayaan masing-masing. Makanan mempunyai arti simbolik, dalam arti memiliki arti sosial, agama dan lain-lain, serta tergolong folklor bukan lisan (Dananjaya, 1991: 182)..

Foster dan Anderson (dlm Dananjaya, 1991; 187-188), menyebutkan bahwa secara simbolis makanan sedikitnya dapat berupa empat ungkapan yakni a) Ikatan sosial, b) Solidaritas kelompok, c) Makanan dan ketegangan jiwa, dan d) Simbolisme makanan dalam bahasa. Hal itu menunjukkan bahwa makanan tradisional (adat) mengandung aspek memperkuat ikatan sosial dan solidaritas sosial dalam kehidupan masyarakat pengembannya. Artinya, makanan tradisional pada suatu masyarakat dengan sendirinya terkait dengan folk culture nya yakni budaya masyarakat pendukungnya. Makanan tradisional suatu daerah bisa menjadi cermin paradaban dan budaya suatu daerah, akan tepat disuguhkan serta dinikmati oleh masyarakat itu pula (Ernayanti, 2003: 2).

Kebiasaan membuat makanan tradisional, sebagaimana diketahui, terdapat dalam kehidupan setiap masyarakat (suku bangsa). Kebiasaan suatu masyarakat yang diwarisi dari generasi sebelumnya lazim juga disebut dengan tradisi 
(tradition). Secara umum, tradisi dianggap sebagai suatu kebiasaan dari kelompok masyarakat pendukung kebudayaan yang penyebaran dan pewarisannya secara turun temurun. Dalam Kamus Besar Bahasa Indonesia (1976), tradisi diartikan sebagai kebiasaan turun temurun yang masih dijalankan dalam masyarakatpendukungnya. Suatu tradisi berhubungan dengan kebiasaan pada suatu komunitas (masyarakat) yang telah berlangsung sejak lama (turun temurun) dan berkaitan dengan aktifitas bersama masyarakat. Tradisi atau kebiasaan tersebut pada dasarnya merupakan cerminan budaya masyarakatnya yang dipelajari dan diwariskan pada generasi selanjutnya. Keberadaan tradisi itu sekaligus memperkuat persatuan dan kesatuan komunitas tersebut, karena dalam kehidupan sehari-hari mereka saling membantu atau bekerjasama.

Tradisi membuat makanan tradisional pada setiap masyarakat pada dasarnya tidak bisa dilepaskan dari budaya masyarakat pendukungnya,sebagai acuan dan mendasari cara pembuatan dan keterlibatan warga suatu kerabat. Dengan memperhatikan cara pengolahannya dan cara penyajiannya, akan diketahui fungsi makanan di dalam kebudayaan masyarakat bersangkutan. Sebuah tradisi pada hakekatnya mempunyai kegunaan atau fungsi sosial bagi masyarakat pendukungnya. Fungsi sosial, dalam Kamus Besar Bahasa Indonesia (1995), diartikan sebagai kegunaan suatu hal bagi hidup suatu masyarakat. Hal ini menunjukkan bahwa segala aktifitas tradisional suatu masyarakat, termasuk membuat makanan tradisional, tidak bisa dilepaskan dari budaya dan merupakan ekspresi masyarakat pengembannya.

Bangsa Indonesia yang majemuk memiliki aneka makanan (kuliner) tradisional yang sekaligus merupakan kekayaan budaya dari masyarakat pendukungnya. Beberapa makanan tradisional yang dimiliki oleh bangsa Indonesia seperti rendang pada masyarakat Minangkabau, pempek pada masyarakat Palembang, betutu pada masyarakat Bali, lemang pada masyarakat Melayu, dan lain-lain. Menurut Wurianto (2008: 3), kuliner tradisional merupakan salah satu kekayaan budaya yang harus digali kembali sebagai salah satu aset kultural melalui revitalisasi dan proses-proses transformasi. Oleh sebab itu, kuliner tradisional 
bukan saja sebagai ilmu tata boga tradisional melainkan dapat juga menjadi ruang pengetahuan dan kearifan lokal.

Salah satu makanan tradisional yang cukup dikenal di Indonesia sejak dahulu adalah lemang. Lemang adalah sejenis makanan yang terbuat dari beras ketan (pulut) yang dicampur dengan air kelapa (santan) serta garam, yang kemudian dimasukkan kedalam bambu yang sudah berlapis daun pisang muda, selanjutnya dimasak pada perapian yang telah disiapkan. Lemang merupakan makanan tradisional khas masyarakat Melayu, terutama yang mendiami Pulau Sumatera, Kalimantan, dan Sulawesi, serta di Semenanjung Malaya (Malaysia), dan masih eksis ditengah masyarakat tersebut hingga sekarang.

Membuat lemang telah menjadi tradisi pada masyarakat Melayudan biasanya dihadirkan atau menjadi menu makanan pada waktu-waktu tertentu, seperti pada bulan puasa (Ramadhan), lebaran, maulud nabi, perkawinan, panen padi, menyambut tamu dan lainnya. Hanya saja, sejak kapan lemang menjadi makanan tradisional pada masyarakat Melayu, tidak diketahui secara pasti dan dari mana asal mula lemang tersebut. Berdasarkan penelitian yang telah dilakukan oleh para ahli menunjukkan bahwa lemang telah ada dalam kehidupan masyarakat Melayu semenjak abad ke 9. Para pendukung pemahaman ini menduga bahwa sejarah lemang telah ada semenjak zaman pra sejarah. Ida Pfeiffer (1852), seorang peneliti dari Austria yang pernah mendatangi tanah Batak, Minangkabau dan Bengkulu, menyebutkan bahwa lemang telah ada di tanah Batak tahun 1852, semenanjung Malaysia tahun 1864, ranah Minangkabau tahun 1873, serta di Bengkulen (Bengkulu) tahun 1900. Hal itu menyiratkan bahwa lemang sebagai makanan tradisional Melayu telah ada jauh sebelum itu atau beberapa waktu silam. ${ }^{1}$

Setiap daerah tersebut memiliki penamaan sendiri untuk menyebut makanan lemang yakni lemang (Melayu), lamang (Minangkabau), dan lomang (Batak). Begitupun dengan tradisi membuat lemang dalam kehidupan sehari-hari, masyarakat (etnis) Minangkabau menyebutnya dengan malamang, masyarakat

\footnotetext{
${ }^{1}$ Asal usul Sejarah Lemang: Apakah di Tanah Batak ? Dikompilasi oleh Akhir Matua Harahap berdasarkan sumber-sumber tempo doeloe.http://akhirmh.blogspot.co.id/2014/12/asal-usulsejarah-lemang-apakah-bermula.html. hlm 8 (tanpa tahun).
} 
Batak di Sumatera Utara menyebut malomang atau mangalomang, di Banyuasin Sumatera Selatan disebut dengan malemang dan di daerah Bengkulu disebut dengan melemang. Walaupun berbeda istilah atau penyebutan, pada dasarnya maksudnya sama yakni tradisi membuat makanan lemang.

Pada masyarakat (suku) Besemah di Kabupaten Kaur Provinsi Bengkulu, lemang telah dikenal sebagai makanan khas (tradisional) semenjak dahulu dan masih eksis hingga sekarang. ${ }^{2}$ Suku Besemah merupakan salah satu suku yang terdapat di Kabupaten Kaur, yang dari segi asal usul berasal dari daerah Pagaralam Sumatera Selatan. Asal-usul penyebutan atau penamaan Besemah bagi komunitas ini, diyakini diambil dari nama ikan semah yang dahulunya banyak terdapat di daerah Pagaralam Provinsi Sumatera Selatan. Ikan semah adalah jenis ikan mas yang hidup di aliran air keruh dan berbatu-batu yang ditumbuhi lumut serta diteduhi pepohonan. Hanya saja, banyak kalangan menyebut suku Besemah ini dengan sebutan suku Pasemah. Penamaan Pasemah ini, konon kabarnya disebabkan karena penjajah Belanda susah melafazkan kata "pa" dan menyebutnya dengan "be", maka istilah "pasemah" disebut dengan "besemah". 3

Masyarakat suku Besemah dan masyarakat lainnya di Kabupaten Kaur biasa menyebut tradisi membuat lemang ini dengan "masak lemang" atau melemang. Tradisi melemang (masak lemang) merupakan bagian yang tidak terpisahkan dari kehidupan sosial budaya masyarakat Besemah sejak dahulu, dan selalu dinantikan ketika tiba masanya membuat lemang secara bersama. Biasanya dilakukan pada bulan Ramadhan (puasa), lebaran (Idul Adha), upacara perkawinan (bimbang), panen padi dan lainnya. Pada waktu itu intensitas hubungan antar keluarga (kerabat) semakin dekat dan akrab karena lemang dimasak secara bersama (gotongroyong) dan dinikmati bersama.

Masyarakat Besemah memiliki kekhasan dalam pelaksanaan tradisi melemang karena lemang menjadi bagian tidak terpisahkan dari rangkaian adat

\footnotetext{
${ }^{2}$ Selain lemang, makanan tradisional masyarakat Kabupaten Kaur adalah gelamai, jambar, lepik binti, cucur bandan, lupis, serabi, kelicuk, tat dan pudding, serta ejinang dan se'awe (BMA, 2014: 1). https://www.pagaralampos.com/2014/01/11/asal-usul-nama-besemah-mengenal-besemah-
rumpun-tertua-di-sumsel/
} 
perkawinan sejak dahulu (turun temurun). Lemang menjadi salah satu makanan yang wajib ada dalam pelaksanaan upacara perkawinan (bimbang), merupakan persyaratan adat dan menentukan keabsahan sebuah perkawinan. Sebuah perkawinan akan dianggap belum lengkap secara adat atau batal (nurung), jika pihak laki-laki (lanang) tidak membawa lemang untuk pihak pengantin perempuan (gadis). Begitu pula, akan menjadi bahan gunjingan di tengah masyarakat terhadap pihak lanang yang tidak membawa lemang ke tempat pengantin perempuan (gadis) dalam pelaksanaan upacara perkawinan. Artinya, lemang tidak hanya sebagai makanan untuk dimakan, tetapi terkait dengan folk culture masyarakat bersangkutan yakni suku Besemah.

Sehubungan dengan itu, tulisan ini mengungkap lebih jauh tentang keberadaan lemang sebagai makanan tradisional Besemah dan fungsinya dalam upacara perkawinan pada suku Besemah di Kabupaten Kaur. Dalam lingkup lebih luas, agar masyarakat umum mengetahui tentang adanya warisan budaya berupa lemang dantradisi melemang pada suku Besemah, dan fungsinya dalam pelaksanaan adat perkawinan (bimbang). Hal tersebut akan memberikan pemahaman yang lebih mendalam dan komprehensif tentang keberadaan lemang dan budaya suku Besemah.

\section{METODE PENELITIAN}

Metode atau pendekatan yang digunakan pada penelitian ini adalah pendekatan kualitatif yang lazim digunakan dalam penelitian kebudayaan yang bertujuan untuk mendapatkan data yang lebih banyak dan mendalam. Dari sifatnya, penelitian ini merupakan penelitian deskriptif analisis untuk menggambarkan lemang sebagai realitas sosial masyarakat Besemah di Kabupaten Kaur. Pengumpulan data menggunakan beberapa teknik yang lazim dipakai dalam penelitian kualitatif yakni studi kepustakaan, wawancara, dan observasi di lapangan. Aplikasi teknik pengumpulan data tersebut sebagai berikut: 
a. Studi Kepustakaan, dengan mengumpulkan artikel, buku, ataupun tulisantulisan yang dapat memberikan informasi tentang keberadaan lemang pada masyarakat Besemah, bertujuan untuk memperoleh gambaran awal tentang tradisi melemang pada masyarakat tersebut.

b. Wawancara dilakukan terhadap beberapa orang informan yang dipilih berdasarkan kriteria yang telah ditetapkan yakni pembuat lemang, pelaksana teknis, tokoh masyarakat/adat, generasi muda, dan lain-lain. Wawancara terfokus dilakukan terhadap informan terpilih (key informant) untuk menggali data yang dibutuhkan. Hasil wawancara ini dianalisa dan dibandingkan dengan data yang diperoleh dari studi kepustakaan untuk memperoleh kelogisan data.

c. Pengamatan dilakukan untuk mengetahui cara pembuatan lemang, pelaksanaan tradisi melemang, lingkungan sosial, lingkungan alam, dan lainnya. Pengamatan penting dalam membandingkan antara data wawancara dengan fakta di lapangan.

Setelah data dan informasi diperoleh, dilakukan analisis data yang dilakukan terus menerus dengan menggunakan teknik interaktif analisis untuk mendapatkan kesinambungan dan kedalaman dalam memperoleh data. Milles dan Huberman (dalam Bungin: 2003), menyebutkan bahwa cara menganalisis data kualitatif dapat dilakukan melalui tiga tahap yaitu :

a. Reduksi data. Diartikan sebagai proses pemilihan pemusatan perhatian pada penyederhanaan, pengabstrakkan dan transformasi data "kasar" yang muncul dari catatan tertulis di lapangan atau mempertegas selama pelaksanaan penelitian. Reduksi data dilakukan dari hasil pengamatan dan wawancara dengan informan dilakukan dengan cara menyusun dan memberikan kategori pada tiap-tiap pertanyaan. Reduksi data berlangsung secara terus menerus selama penelitian. Setelah data terkumpul maka data tersebut diseleksi, diolah, dipilih, disederhanakan, difokuskan, dan mengubah data kasar kedalam catatan lapangan. 
b. Display data atau penyajian data. Setelah melakukan reduksi data maka dilakukan pengelompokan data secara tersusun agar memudahkan peneliti dalam melihat gambaran secara keseluruhan atau bagian-bagian tertentu dari penelitian. Setelah dilakukan penelitian dan pemberian kategori pada tiap-tiap pertanyaan reduksi data, maka data tersebut dikelompokkan sesuai dengan permasalahan penelitian.

c. Penarikan kesimpulan (verifikasi). Dilakukan setelah reduksi data dan penyajian data sehingga akhirnya dapat ditarik kesimpulan. Dalam verifikasi (penarikan kesimpulan) berdasarkan pada informasi yang diperoleh di lapangan atau melakukan interpretasi data, sehingga dapat memberikan penjelasan dengan jelas dan akurat.

Selanjutnya data dan informasi yang didapat dari lapangan dan sumber lain diolah, dianalisa dan dideskripsikan, sehingga diperoleh gambaran tentang lemang dan tradisi melemang dalam kehidupan masyarakat Suku Besemah di Kabupaten Kaur Provinsi Bengkulu.

\section{PEMBAHASAN}

\section{Sekilas Kabupaten Kaur dan Suku Besemah}

Kabupaten Kaur merupakan salah satu kabupaten di Provinsi Bengkulu, terletak di bagian selatan berbatasan langsung dengan Provinsi Lampung, sebelah Utara dengan Kabupaten Bengkulu Selatan dan Kabupaten Lahat Provinsi Sumatera Selatan, sebelah Barat dengan Samudera Hindia, dan sebelah Timur dengan Provinsi Sumatera Selatan. Pusat pemerintahan (ibukota kabupaten) berada di Bintuhan Kecamatan Kaur Selatan, yang berjarak sekitar 250 km dari Kota Bengkulu (ibukota provinsi). Kabupaten Kaur dibentuk berdasarkan Undang-undang (UU) Nomor 3 tahun 2003 bersama-sama dengan Kabupaten Seluma dan Kabupaten Muko-muko di Provinsi Bengkulu. ${ }^{4}$

\footnotetext{
${ }^{4}$ Kabupaten Kaur dan Kabupaten Seluma dahulunya merupakan bagian dari Kabupaten Bengkulu Selatan, sedangkan Kabupaten Mukomuko merupakan pemekaran dari Kabupaten Bengkulu Utara.
} 
Kabupaten Kaur mempunyai keragaman suku bangsa (etnis), ditandai dengan beberapa suku asal yang telah mendiami daerah itu secara turun temurun, serta penduduk pendatang dari daerah lain. Penduduk asal Kabupaten Kaur adalah suku (orang) Kaur, Besemah, dan Semende. Suku Kaur mendiami bagian selatan, suku Besemah (Pasemah) mendiami bagian utara dan berbatasan langsung dengan Kabupaten Bengkulu Selatan, sedangkan suku Semende di Kecamatan Muara Sahung dan sebagian Nasal yang berbatasan dengan Provinsi Sumatera Selatan. Penduduk pendatang di Kabupaten Kaur cukup beragam antara lain suku Minang, Melayu, Batak, Jawa, Lampung, Palembang dan lainnya. Sebagian besar suku Jawa dahulunya merupakan transmigran yang tinggal di beberapa unit pemukiman transmigrasi, baik yang masih dalam pembinaan maupun telah menjadi desa definitif. Suku Batak, Minang, Palembang dan Lampung merupakan transmigran spontan, dimana mereka datang karena kepentingan berdagang, perkawinan dan lainnya. ${ }^{5}$

Suku Besemah di Kabupaten Kaur, sebagaimana telah diungkapkan, datang dari Pagaralam Sumatera Selatan beberapa abad silam. ${ }^{6}$ Mereka membentuk komunitas sendiri sebagai orang Besemah dan memiliki budaya yang sama dengan daerah asalnya tersebut. Suku Pasemah di Kabupaten Kaur, mendiami Kecamatan Kelam Tengah, Tanjung Kemuning, Lungkang Kule, Kinal, Kaur Utara, Padang Guci Hulu, Padang Guci Hilir, dan berbatasan langsung dengan Kabupaten Bengkulu Selatan. ${ }^{7}$ Dalam kesehariannya, masyarakat (suku) Besemah Kabupaten Kaur tetap melaksanakan adat Besemah sebagaimana halnya di Pagaralam, Sumatera Selatan. Suku Besemah menggunakan sistem keturunan berdasarkan patrilinial (garis ayah), dimana seseorang yang terlahir akan masuk jurai (sumbai) ayahnya. Dalam perkawinan, proses peminangan pertama kali adalah inisiatif dari pihak laki-laki (lanang) kepada pihak perempuan (gadis), atau

\footnotetext{
${ }^{5}$ http://kabkaur.blogspot.com/

${ }^{6}$ Daerah asal Suku Besemah di Sumatera Selatan meliputi daerah sekitar Kota Pagaralam, serta Kecamatan Jarai dan Kecamatan Tanjung Sakti Kabupaten lahat yang berbatasan dengan wilayah Bengkulu (Asrin dkk, 2016)

${ }^{7}$ Orang (suku) Besemah juga terdapat di Kecamatan Kedurang Kabupaten Bengkulu Selatan yang wilayahnya berbatasan langsung dengan wilayah suku Besemah di Kabupaten Kaur (Padang Guci).
} 
pihak laki-laki yang melamar pihak perempuan. Sekalipun masyarakat Besemah memakai sistem patrilinial, mereka tidak mempunyai aturan yang ketat tentang pola menetap setelah menikah. Mereka bebas memilih dimana bertempat tinggal sesuai dengan kesepakatan kedua belah pihak sebelum berlangsungnya pernikahan. Penetapan tempat tinggal setelah menikah pada masyarakat Besemah, menurut Susanto (2011: 38-39), ada 3 macam yakni:

\section{Perkawinan Kule Berete/Belaki (Perkawinan Jujur)}

Pada perkawinan Kule Berete semua kegiatan termasuk peminangan dengan segala tata caranya dilakukan oleh pihak laki-laki. Seorang isteri mengikuti suami atau bertempat tinggal di lingkungan kerabat suaminya itu. Anak-anak yang dilahirkan dari perkawinan menjadi penerus keturunan suami.

\section{Perkawinan Kule Teambik Anak (Semendo)}

Pada perkawinan Kule Teambik Anak, semua kegiatan termasuk peminangan dengan segala tata caranya dilakukan oleh pihak keluarga perempuan, dan suami bertempat tinggal di rumah isteri (keluarga isteri). Anakanak yang dilahirkan dari perkawinan tersebut menjadi penerus keturunan isteri (pihak keluarga isteri). Biasanya tidak ada uang antaran yang diberikan oleh calon pengantin laki-laki kepada calon pengantin perempuan.

\section{Perkawinan Jurai Sesame (Semendo Rajo-Rajo)}

Pada perkawinan jurai sesame, semua kegiatan dilakukan berdasarkan musyawarah mufakat antara kedua belah pihak (pihak calon suami dan pihak calon isteri). Dalam menentukan tempat tinggal setelah menikah berdasarkan pada kesepakatan bersama, sedangkan anak-anak yang dilahirkan dari perkawinan menjadi penerus keturunan kedua belah pihak.

Pada umumnya sekarang, masyarakat Besemah menggunakan pola menetap setelah menikah semendo rajo-rajo (jurai sesame) yang memberi kebebasan pada kedua pengantin untuk dimana tinggal setelah menikah. Jika, ada warga masyarakat yang mempunyai hajat mengawinkan anaknya, maka akan 
memberitahukan hal itu kepada semua keluarganya. Hal itu berlanjut dengan diadakannya pertemuan (musyawarah) dengan keluarga dekat (adik sanak) di rumahnya. Pada musyawarah (rasan kule) tersebut, dibicarakan dimana kedua pengantin akan bertempat tinggal (menetap) setelah menikah, serta dibahas kewajiban pihak laki-laki membawa lemang ke tempat pihak perempuan, sebagaimana yang telah belaku turun temurun. ${ }^{8}$

\section{Lemang dan Tradisi Melemang}

Lemang, merupakan makanan (kuliner) khas masyarakat di Kabupaten Kaur, bahkan menjadi kebanggaan masyarakat setempat sejak dahulu sebagai warisan dari leluhur (puyang). Lemang tidak hanya terdapat pada suku Besemah melainkan juga pada suku Kaur dan suku Semende. Lemang menjadi makanan yang selalu dihadirkan dalam peringatan hari-hari keagamaan (Islam), panen padi, menyambut tamu dan upacara perkawinan. Lemang dimasak dengan menggunakan bambu berukuran diameter $3 \mathrm{~cm}$ dan panjang $25 \mathrm{~cm}$. Sekarang, lemang menjadi icon kuliner masyarakat Kabupaten Kaur dan merupakan kekayaan budaya yang diupayakan kelestariannya. ${ }^{9}$

Keberadaan lemang di bumi Besemah dan Kaur umumnya, tidak diketahui secara pasti, kapan dan siapa yang membuat awalnya, masyarakat setempat telah mendapati lemang sebagai makanan yang dihidangkan ketika ada peringatan hari besar agama Islam, panen padi, kenduri (selamatan), upacara perkawinan, menyambut tamu dan lainnya. Masyarakat Besemah (Pasemah) di Kabupaten Kaur, menganggap bahwa lemang merupakan makanan yang keberadaannya pertama kali adalah di bumi Besemah dan kemudian baru menyebar ke daerah lain di Sumatera. Disebutkan bahwa lemang telah ada dalam kehidupan masyarakat Besemah semenjak abad ke 15, saat keberadaan sebuah kerajaan bernama Bajau Sakti di daerah tersebut dahulunya. Kerajaan Bajau Sakti disebutkan sebagai

\footnotetext{
${ }^{8}$ Lemang sebagai bagian dari pelaksanaan upacara perkawinan (bimbang) juga terdapat pada masyarakat Suku Semende (Semendo) di Kabupaten Kaur dan Suku Serawai yang mendiami Kabupaten Bengkulu Selatan dan Kabupaten Seluma.

${ }^{9}$ Lemang telah diakui sebagai warisan budaya masyarakat Kabupaten Kaur oleh Kementerian Pendidikan dan Kebudayaan pada tahun 2019.
} 
kerajaan tertua di Sumatera, yang konon lebih tua dari Kerajaan Sriwijaya, dengan pusat pemerintahannya berada di daerah Tanjung Iman Kecamatan Kaur Tengah sekarang. Hanya saja, peninggalan-peninggalan dari kerajaan tersebut tidak ditemukan lagi sekarang. ${ }^{10}$

Lemang sebagai persyaratan adat (makanan adat) dalam upacara perkawinan suku Besemah, ditetapkan di masa Kerajaan Bajau Sakti tersebut. ${ }^{11}$ Pada masa itu, lemang telah ditetapkan sebagai makanan yang mesti ada dalam pelaksanaan upacara perkawinan (bimbang) pada masyarakat setempat (Besemah). Lemang menjadi hantaran (bawaan) wajib pihak pengantin laki-laki (lanang) kepada pihak pengantin perempuan (gadis). Dijadikannya lemang sebagai makanan bawaan (hantaran) dari pihak laki-laki (makanan adat), disebabkan karena pada waktu itu lemang merupakan makanan yang paling enak dan sehat. Dalam perkembangan kemudian, lemang menjadi makanan yang selalu dihidangkan pada waktu perayaan hari besar agama Islam, panen padi, selamatan dan lainnya. Hal itu menunjukkan bahwa tradisi melemang (masak lemang) pada masyarakat Besemah telah berlangsung sejak beberapa abad silam. Dijadikannya lemang sebagai makanan bawaan dalam upacara perkawinan suku masih bertahan hingga sekarang dalam kehidupan suku Besemah.

Dalam kehidupan masyarakat Besemah, dan masyarakat Kabupaten Kaur umumnya ada banyak nama-nama untuk menyebut makanan lemang ini, diantaranya lemang pengantin, lemang palayan, lemang bujang betuntut, lemang pelayan, lemang bakul fitrah, lemang maulid, dan lemang selesai panen padi. Masing-masing nama, berkaitan dengan fungsi dan waktu, masakan lemang disajikan sebagai hidangan utama suatu acara adat-budaya (BMA, 2014, 2). Berdasarkan bahannya dikenal adanya lemang gemuk, lemang pisang, lemang ubi dan lainnya. Selain itu dikenal juga lemang berdasarkan campuran atau kawan makannya, seperti lemang tapai yang merupakan campuran lemang bersama

\footnotetext{
${ }^{10}$ Berdasarkanhasil wawancara dengan Bpk. Kastadinata di Desa Rigangan 1 Kecamatan Kelam Tengah Kabupaten Kaur pada tanggal 22 Juli 2018.

${ }^{11}$ Ditetapkan oleh Rifabing yang merupakan anak dari Raja Alif dari Kerajaan Bajau Sakti, berdasarkan informasi dari Bpk. Kastadinata Kecamatan Kelam Tengah.
} 
tapai. ${ }^{12}$ Walaupun jenis dan varian dari lemang bermacam-macam, namun dalam proses pembuatannya dan bahannya relatif sama.

Lemang pada pelaksanaan upacara perkawinan (bimbang) biasa disebut juga dengan lemang perkulean oleh masyarakat Besemah, dan lemang yang digunakan sebagai bawaan pihak laki-laki (lanang) adalah lemang gemuk. Lemang gemuk ditandai dengan buluh (bambu) yang dugunakan berwarna putih, karena kulit bambu itu telah dikupas kulitnya terlebih dahulu. Berbeda dengan lemang lainnya yang biasanya tidak dikupas kulitnya (tetap berwarna hijau lumut) seperti warna bambu umumnya. Penamaan lemang dalam pelaksanaan upacara perkawinan pada suku Besemah disesuaikan dengan konteks peruntukkannya ketika itu, seperti lemang pengantin, lemang pelayan, lemang betuntut dan lainnya. Lemang pengantin merupakan lemang yang diperuntukkan untuk pihak pengantin perempuan, lemang pelayan sebagai lemang yang diberikan pada pemimpin masyarakat yakni kepala desa (depati) sebagai unsur pemerintahan. ${ }^{13}$ Lemang betuntut adalah lemang untuk bujang betuntut yang merupakan utusan pihak perempuan ketika mengunjungi rumah pihak lanang (laki-laki). Artinya, bermacam nama lemang itu menunjukkan pemanfaatan (fungsi) lemang itu dalam pelaksanaan upacara perkawinan suku Besemah, walau secara fisik lemangya sama yakni lemang gemuk. Hal itulah yang menyebabkan menarik dan uniknya keberadaan lemang dalam kehidupan masyarakat suku Besemah.

Pembuatan lemang membutuhkan waktu yang relatif lama, mulai dari mencari bambu sampai selesai. Jika dihitung dari proses mencari bambu hingga lemang siap untuk dimakan (masak), membutuhkan waktu paling cepat 2 (dua) hari. Proses pengolahan bahan membutuhkan waktu satu hari (sehari), sedangkan untuk memasak lemang dibutuhkan waktu lebih kurang 3 jam. Bahan-bahan

\footnotetext{
${ }^{12}$ Lemang tapai merupakan makanan yang terbuat dari beras pulut yang dicampur dengan santan (air kepala yang diperas), serta tapai (beras hitam). Tapai adalah makanan pelengkap lemang yang membuat lemang terasa lebh enak, namun keduanyanya bisa dimakan sendiri-sendiri (Refisrul, 2010: 2007). Lemang tapai banyak dijual di pasar (kalangan) di Provinsi Bengkulu seperti Kota Bengkulu, Manna dan Bintuhan. Di Pasar Masat di Bengkulu Selatan, lemang dijual pada setiap Kamis malam.

${ }^{13}$ Depati merupakan pemimpin masyarakat di tingkat dusun (kampung) pada masa dulu, sebelum diberlakukannya sistem pemerintahan desa tahun 1980-an di Provinsi Bengkulu.
} 
(perlengkapan) yang dibutuhkan dalam membuat lemang antara lain beras pulut (ketan), bambu, santan, daun pisang, lebe, garam, air kince, dan kemiri. Tahapan pembuatan lemang dari awal hingga akhir yakni mencari bambu, memotong dan membersihkan bambu, memotong membersihkan pucuk daun pisang, memasukkan daun pisang ke dalam buluh (bambu), membersihkan dan memasukkan beras kedalam bambu, mengambil isi kelapa, meremas isi kelapa menjadi santan, memasukkan santan ke dalam bambu, membuat tetayan (tempat menyandarkan lemang waktu dimasak), membawa lemang ke tetayan untuk dimasak. Setelah lemang masak, selanjutnya dibawa kedalam rumah dan diletakkan pada tempat yang telah disiapkan sebelum dibawa kerumah pihak pengantin perempuan (gadis). Pihak yang bertanggungjawab dalam pelaksanaan tradisi melemang adalah orang yang punya hajat mengawinkan anaknya. Melemang (masak lemang) ini tidak hanya melibatkan orang yang punya hajat, tetapi juga melibatkan pihak lain seperti adik sanak (kerabat), tetangga, dan kepala desa sebagai unsur pemerintahan. Pada waktu itu, keluarga dekat (adik sanak), akan membantu mulai dari mencari bambu, memasak dan menyiapkan lemang untuk dibawa ke tempat pengantin perempuan. Pada waktu musyawarah membicarakan perkawinan, akan dibicarakan berapa batang lemang yang akan dibantu oleh masing-masing kerabat tersebut. Banyaknya lemang yang dibawa oleh para kerabat itu akan dicatat dan dihitung apakah sudah mencukupi dibawa sebagai hantaran ke rumah pihak pengantin perempuan.

\section{Lemang dalam Upacara Perkawinan}

Perkawinan, sebagaimana diketahui, merupakan saat yang penting bagi kehidupan dua insan manusia (laki-laki dan perempuan) dalam ikatan kasih yang diharapkan berlangsung sepanjang hayat. Pada masyarakat Besemah, rangkaian ikatan perkawinan antara seorang laki-laki (lanang) dengan seorang perempuan (gadis) mengikuti adat yang berlaku pada masyarakat Besemah turun temurun. Dalam adat perkawinan suku Besemah ada ketentuan bahwa pihak pengantin lakilaki akan memberikan beberapa batang lemang kepada pihak perempuan. Lemang menjadi bawaan wajib yang tidak boleh diabaikan, karena bisa menyebabkan 
perkawinan itu menjadi batal (nurung). Oleh karenanya, lemang menjadi unsur yang penting dalam upacara perkawinan adat suku Besemah sejak dahulu hingga sekarang.

Dalam adat Besemah, ada 3 (tiga) tahapan perkawinan yang harus menghadirkan lemang sebagai bawaan pihak pengantin laki-laki untuk pihak pengantin perempuan (BMA, 2014: 60), yakni :

a. Saat perundingan antara kedua belah pihak untuk menetapkan hari atau malam pernikahan. Pada waktu musyawarah keluarga pihak mempelai lakilaki diharuskan membawa lemang sebanyak 10 batang.

b. Saat rombongan mempelai laki-laki mengantarkan pengantin laki-laki ke rumah pengantin perempuan sebanyak 65 batang lemang.

c. Saat acara pesta pernikahan (kagu'an) sebanyak 50 batang, khususnya ketika pengantin laki-laki akan mengantar kerbai pengantin perempuan kerumahnya.

Hal diatas menunjukkan bahwa lemang merupakan makanan paling dominan yang harus ada diantara sekian banyak jenis makanan lain. Artinya, dalam setiap bentuk perkawinan dalam adat Besemah, lemang selalu menjadi bagian dari hantaran (bawaan) pihak pengantin laki-laki (lanang) untuk pihak pengantin perempuan (gadis). Bahkan, lemang juga menjadi persyaratan yang harus diadakan pada waktu selarian (kawin lari) dan ketika perkawinan itu dibatalkan (nurung).

Adat (upacara) perkawinan pada masyarakat Besemah, pada dasarnya telah dimulai setelah adanya kesepakatan antara bujang dan gadis untuk menikah. Orangtua pihak laki-laki akan datang kerumah pihak perempuan menanyakan apakah anak bujangnya memang sudah ada kemufakatan dengan anak gadis tuan rumah untuk menikah. Kegiatan ini dinamakan dengan nue'i rasan atau merasan. Pada waktu ini pihak laki-laki belum membawa lemang, tetapi membawa makanan lain yakni boak (lemak manis) dan pisang goreng. Boak adalah makanan yang terbuat dari isi kelapa yang diparut bercampur gula merah, sedangkan pisang goreng adalah buah pisang yang digoreng bercampur tepung. Penggunaan boak dan lemang dalam upacara perkawinan mempunyai makna atau simbol tersendiri. 
Jika yang dibawa boak tanpa lemang berarti acara itu masih tingkat keluarga (belum acara adat), tetapi jika sudah membawa lemang maka sifatnya lebih tinggi atau merupakan acara adat (rasan kule), karena melibatkan masyarakat yang lebih luas dan dihadiri oleh kepala desa dan pemuka adat.

Lemang yang dijadikan sebagai bawaan (makanan) dalam perkawinan, sebagaimana diketahui, adalah lemang gemuk, dan lemak manis (boak) sebagai teman makan lemangnya. Dijadikannya lemak manis sebagai teman makan lemang disebabkan lemang gemuk akan membuat lemang semakin manis apabila dimakan dengan lemak manis. Lemang gemuk dan lemak manis sebagai makanan adat dalam upacara perkawinan mengandung filosofi sendiri yang mencerminkan pola fikir leluhur orang Besemah dahulunya. Ibaratnya, lemak manis (boak) dianggap melambangkan perempuan, sedangkan lemang gemuk melambangkan laki-laki. Lemak manis diibaratkan sebagai pakaian wanita, dan lemang gemuk sebagai alat laki-laki. Makanya, pertemuan lemang dan lemak manis merefleksikan pertemuan antara laki-laki dengan perempuan dalam ikatan perkawinan sebagai sebagai suami isteri.

Pada waktu peminangan (melamar) oleh pihak laki-laki kepada pihak perempuan, orangtua calon pengantin laki-laki akan datang ke tempat perempuan ditemani kaum kerabatnya (adik sanak), dengan membawa lemang gemuk sebanyak 10 batang dan pisang goreng, sedangkan boak (lemak manis) tidak dibawa lagi. Bawaan (hantaran) itu harus dilengkapi dengan tungking yang berisikan sirih, gambir, pinang, tembakau, dan lainnya. Tungking merupakan syarat utama dalam adat Besemah yang bermakna menyatukan kesepakatan antara dua keluarga dalam ikatan perkawinan antara anak mereka. Apabila telah ada kesepakatan di tingkat keluarga dekat (adik sanak), maka pihak tuan rumah akan mengundang kepala desa, pemuka adat dan lainnya menghadiri pertemuan (musyawarah), sekaligus memberitahukan rencana pelaksanan pesta pernikahan (kagu'an). Pesta perkawinan (kagu'an) diadakan di tempat kedua belah pihak, pada hari pertama dilaksanakan di tempat pihak perempuan dan besoknya di rumah pihak laki-laki. 
Pada waktu pertunangan, pihak laki-laki (lanang) membawa lemang sebanyak 10 batang (lemang 10) yangmenandai terciptanya hubungan antara bujang dengan gadis dalam ikatan pertunangan. ${ }^{14}$ Lemang itu menandai berubahnya tuturan (sebutan/panggilan) dari kedua belah pihak, ayah bujang akan memanggil calon menantunya dengan sebutan 'nak', ayah bujang memanggil ayah gadis dengan "warang (besan)", sedangkan ibu bujang memanggil ibu gadis dengan "bisan (besan)", begitupun sebaliknya. Pihak perempuan akan membalas bawaan dari pihak laki-laki itu dengan makanan bajik dan pisang goreng. Pada waktu itu disepakati pula kapan pelaksanaan pernikahan (kagu'an) antara bujang (lanang) dan gadis, serta dimana kedua pengantin bertempat tinggal setelah menikah. Biasanya jarak waktu pertunangan dengan waktu pernikahan adalah 1 bulan.

Lemang dari pihak laki-laki akan dijadikan sebagai alat pemberitahuan oleh pihak gadis pada adik sanak (kerabat) agar berkenan hadir pada pesta pernikahan (bimbang) keesokan harinya. Lemang itu dipotong-potong dan potongan itu diberikan pada mereka yang diharapkan hadir pada kagu'an esok hari. Artinya, pemberian potongan lemang itu sebagai bentuk pengundangan dari tuan rumah (rumah pokok). Sebatang lemang dipotong kecil-kecil secara menyamping (menyerong) dan diberikan kepada orang yang diundang pada sore hari sebelum hari kagu'an. Maksud dari pembagian lemang ini untuk mengingatkan orang yang diundang tersebut bahwa pengantin akan datang dan pesta perkawinan (pernikahan) akan dilangsungkan besok pagi. Menurut adat setempat, bagi yang mendapatkan potongan lemang, mereka wajib membawa nasi satu bungkus yang dibungkus dengan daun, gulai atau lauk pauk, dan kue (Susanto, 2011; 48). Nasi bungkus itu nantinya akan diperuntukan untuk tamu yang datang.

Pada waktu kagu'an, pengantin laki-laki kembali membawa lemang ditambah makanan lain dengan jumlah yang lebih banyak, tetapi tanpa boak (lemak manis). Lemang yang dibawa oleh rombongan pihak laki-laki (lanang)

\footnotetext{
${ }^{14}$ Masyarakat Besemah, menyebut banyaknya lemang yang dibawa dengan menyebut kata "lemang" yang diikuti dengan jumlah lemang tersebut, seperti 10 batang lemang disebut dengan lemang 10, 50 batang lemang disebut dengan lemang 50, dan lain-lain.
} 
diikat dengan daun pisang sesuai peruntukannya yang telah ditetapkan secara adat yakni untuk pihak pengantin perempuan, kepala desa dan lainnya. Lemang yang dibawa sebanyak 50 batang dengan rincian peruntukannya adalah 10 batang untuk orang tua perempuan, 10 batang untuk saudara laki-laki orang tua perempuan, 10 batang untuk pengantin perempuan, 10 batang untuk pengantin laki-laki, dan 10 batang untuk kepala desa. Selain lemang sebanyak 50 batang itu, disertai pula dengan makanan lain yakni lemak manis (boak) sebagai pertanda menjemput pengantin perempuan, gulai paha ayam untuk kepala desa, lemang kampek 15 batang (untuk keluarga terdekat dan adik sanak terdekat), dan bronang berisi lemang 15 batang (untuk cadangan di rumah calon pengantin perempuan).

Lemang pengantin adalah lemang yang diperuntukkan bagi pengantin perempuan dan keluarganya oleh pihak pengantin laki-laki, dan menjadi persyaratan secara adat agar perkawinan itu bisa diterima ditengah masyarakat. Makna (simbol) dari lemang itu adalah penjemputan pengantin perempuan untuk dibawa ke tempat laki-laki. Lemang pelayan adalah lemang yang diperuntukkan bagi kepala desa (depati) sebagai pertanda hormat pada pimpinan yang ikut menyukseskan perkawinan tersebut. Lemang betuntut adalah lemang yang dibawa pihak pengantin perempuan ke rumah pengantin laki-laki setelah pernikahan (kagu'an). Hal itu menunjukkan bahwa lemang mempunyai arti penting bagi masyarakat Besemah di Kabupaten Kaur, karena hampir seluruh aktifitas sosial budanya terkait dengan lemang, terutama dalam upacara perkawinan.

Setelah pernikahan (kagu'an) dirumah perempuan, seterusnya pihak pengantin perempuan akan diantar kerumah pihak pengantin laki-laki dengan membawa bronang berisi lemang 10 (bake bunting) dan makanan lainnya. ${ }^{15}$ Orang yang mengiringi pengantin perempuan ke rumah pengantin laki-laki terdiri dari 5 orang gadis yang lazim disebut gadis ngangkat (kawan mempelai perempuan), kerbai (perempuan yang sudah kawin), dan 1 orang laki-laki dewasa. Diiringi pula oleh paling sedikit 10 orang dan paling banyak 15 orang laki-laki yang lazim disebut dengan "bujang betuntut". Prosesi mengiringkan pengantin

\footnotetext{
${ }^{15}$ Wawancara dengan Bpk. Maksan, Pengurus Lembaga Adat Kabupaten Kaur di Desa Tanjung Sakti 1 Kecamatan Kelam Tengah Kabupaten Kaur pada tanggal 20 Juli 2018.
} 
perempuan dengan membawa lemang itu dinamakan dengan mendah. Secara adat, rombongan pihak perempuan yang datang ke tempat laki-laki merupakan tamu adat bagi pihak laki-laki.

Selain pada waktu meminang dan resepsi perkawinan (kagu'an), lemang juga dihadirkan ketika terjadi kawin lari (selarian), ketika seorang bujang (pemuda) membawa pergi seorang gadis kerumahnya. Jika hal itu diketahui oleh kedua orang tua si gadis dan sanak family (keluarga), kepala desa dan lainnya. Pihak calon pengantin laki-laki diharuskan membawa 10 batang lemang ke rumah pihak perempuan, dan 10 batang lemang pula untuk kepala desa sebagai tanda memberitahukan selarian tersebut. Lemang 10 batang itu bisa disusul atau dibawa pada waktu pernikahan (kagu'an) sesuai dengan kesepakatan kedua belah pihak. Seandainya pernikahan antara bujang dan gadis tidak jadi atau batal (nurung), maka menurut adat, pihak laki-laki harus membawa lemang sebanyak 10 batang (lemang 10) dan lemak manis (boak) untuk melakukan acara kule masam, dan lemangnya disebut dengan lemang kule masam. Kalau sudah bawa lemang kule masam, maka ada 2 (dua) alternatif bagi perjanjian pernikahan itu yakni dilanjutkan atau tidak jadi (nurung).

Berdasarkan hal diatas, dapat diketahui bahwa lemang bagi suku Besemah menjadi simbol dari sebuah perkawinan, atau menjadi titian adat menuju kehidupan baru antara seorang laki-laki dengan seorang perempuan. Sekaligus sebagai bentuk penghormatan (simbol) kehormatan dari pihak pengantin laki-laki terhadap pihak pengantin perempuan. Dalam lingkup lebih luas, lemang merupakan simbol supremasi adat Besemah, sebagaimana yang telah ditetapkan oleh para leluhurnya (puyang) dahulu.

Makanan lemang dan tradisi melemang sebagai produk budaya masyarakat Besemah, mengandung nilai budaya yang mencerminkan budi luhur masyarakat pendukungnya. Salah satu nilai budaya yang terkandung adalah nilai sosial yang tercermin dari kerjasama (kegotongroyongan) dalam pembuatan lemang dan sebagai persyaratan adat dalam upacara perkawinan. Nilai budaya lainnya adalah nilai keagamaan, ekonomi dan historis. Seperti disebutkan Zulfa (2014: 68) bahwa tradisi melemang mempunyai nilai-nilai kegotongroyongan, nilai kebersamaan, nilai tanggungjawab dalam kehidupan masyarakat 
pendukungnya. ${ }^{16}$ Adanya kerjasama (gotongroyong) itulah menjadikan lemang dan tradisi melemang tetap eksis dalam kehidupan suku Besemah sejak dahulu hingga sekarang.

\section{PENUTUP}

Pada suku Besemah, lemang menjadi makanan adat dalam pelaksanaan upacara perkawinan (bimbang), khususnya sebagai bawaan wajib oleh pihak lanang (laki-laki) kepada pihak perempuan. Hal itu menunjukkan bahwa lemang sebagai makanan tradisional masyarakat Besemah mempunyai fungsi sosial dan mengandung nilai budaya luhur yang patut dipertahankan. Kekhasan lemang dalam kehidupan suku Besemah ditandai dengan dijadikannya lemang sebagai persyaratan adat dalam upacara perkawinan.

Fungsi sosial lemang dan nilai budaya dalam tradisi melemang menjadi faktor yang menyebabkan masih eksisnya lemang dalam kehidupan masyarakat Besemah di Kabupaten Kaur hingga sekarang. Lemang menjadi simbol terciptanya ikatan perkawinan antara seorang bujang (lanang) dengan seorang perempuan (gadis), dan keabsahan perkawinan itu ditengah masyarakat (titian adat). Lemang sebagai simbol kepedulian dan kedekatan seorang pengantin lakilaki terhadap keluarga besarnya yang baru yaitu keluarga pengantin perempuan. Disamping itu, menandakan penghormatan dari pihak pengantin laki-laki terhadap pihak pengantin perempuan, serta kepala desa dan tokoh adat sebagai pemimpin.

Lemang merupakan titian adat atau simbol kemuliaan bertujuan untuk memperkokoh dan mempererat hubungan pihak pengantin laki-laki-laki (lanang) dengan pihak pengantin perempuan (gadis) dalam ikatan perkawinanpada suku Besemah. Lemang adalah keniscayaan kultural, yang apabila dilupakan maka akan melahirkan suatu hukuman kultural pula. Hal itu menunjukan bahwa lemang menjadi makanan yang sakral dalam kehidupan masyarakat Besemah sejak dahulu hingga sekarang.

\footnotetext{
${ }^{16}$ Berdasarkan penelitiannya tentang Sistem Pola Pewarisan Malamang di Kota Padang tahun 2014, menunjukkan bahwa sistem pola pewarisan tradisi malamang di Kota Padang tidak berjalan dengan baik, bahkan hampir tidakada.
} 


\section{DAFTAR PUSTAKA}

Aritonang, Baharuddin. 2008. Orang Batak Berpuasa. Jakarta: Kepustakaan Reguler Gramedia

Asrin. 2016. "Budaya Perkawinan Suku Pasemah di Padang Guci Bengkulu". Tesis. Program Pascasarjana IPS FKIP Universitas Lampung

Badan Musyawarah Adat Kaur. 2014, Khazanah Budaya Kaur, Seni Tari, Tutur, Pencak Silat, Masakan Tradisional dan Artefak. Yogyakarta: LP2B

BPS Kabupaten Kaur. 2017. Statistik Daerah Kabupaten Kaur 2016. Bintuhan: BPS Kabupaten Kaur

Bungin, Burhan. 2003. Analisis Data Penelitian Kualitatif, Jakarta PT. Raja Grafindo Persada

Dananjaya, James. 1991. Folklor Indonesia, Ilmu Gosip, Dongeng dan Lain-lan. Jakarta: Grafiti Press

Depdikbud. 2001. Kamus Besar Bahasa Indonesia. Jakarta: Balai Pustaka

Ernayanti. 2003. "Strategi Pengembangan Kuliner Tradisional". Skripsi. Denpasar: UNUD Bali.

Koentjaraningrat. 1979. Pengantar Ilmu Antropologi. Jakarta: Aksara Baru.

Poerwadarminta. 1976. Kamus Umum Bahasa Indonesia. Jakarta: Balai Pustaka

Refisrul dkk. 2010. "Inventarisasi Karya Budaya Kabupaten Bengkulu Selatan dan Kabupaten Kaur Provinsi Bengkulu”. Laporan Penelitian. BPSNT Padang.

Susanto, Lekap Harya. 2011. "Perubahan Rangkaian Upacara Perkawinan Adat Daerah Kaur Utara". Skripsi. Bengkulu: Fakultas Ilmu Sosial dan Ilmu Politik Universitas Bengkulu.

Sutarto, Dendi. 2012. "Kearifan Budaya Lokal dalam Pengutan Tradisi Malemang di Tengah Masyarakat Modernisasi di Sungai Keruh Musi Banyuasin Sumatera Selatan".Makalah. Disampaikan pada Seminar Kepemimpinan Kepemudaan Madya Kementerian Pemuda dan Olahraga RI PUSKAKEM Universitas Sriwijaya di Hotel Aston Palembang, 2-6 Oktober 2012.

Wurianto, Arif Budi. 2008. "Aspek Budaya pada Tradisi Kuliner Tradisional di KotaMalang sebagai Identitas Sosial Budaya (Sebuah Tinjauan Folklore)". 
Laporan Penelitian. Malang: Lembaga Penelitian Universitas Muhammadyah Malang.

Zulfa dan Kaksim. 2014, "Sistem Pola Pewarisan Tradisi Malamang di Kota

Padang", dalam Jurnal Kajian Budaya Vol. 10. No. 20, Juli 2014. Padang: STKIP PGRI Sumatera Barat 